\title{
A Critical Review of the Proposed Remedies for the Darfur Victims of International Crimes
}

\author{
Tambe Endoh Fabrice
}

Faculty of Law, University of Fort Hare, PB X1314, Alice 5700, South Africa

Doi:10.5901/mjss.2014.v5n9p231

Email: fablosa88@yahoo.com

\begin{abstract}
The crimes committed in Darfur have captured more attention from the international community. In the year 2005 the United Nations Security Council adopted resolution 1593 to refer the Darfur case file to the International Criminal Court for proper clarifications as to whether or not genocide occurred in the region. The outcome of the Court's final judgment will be of paramount importance. However, the International community is of the opinion that, acts of human rights violation have been perpetrated against an identifiable group of people in Darfur. For the interest of justice and the enforcement of international law, there is need for legal authorities to respond to the plight of the victims of the conflict. This paper explores the remedies available for the Darfur victims of international crimes and in conclusion the author argues in favor of a reparation commission to redress the plight of the victims of the conflict.
\end{abstract}

Keywords: Remedies, Victims, Darfur, International Crimes, Reparation Commission, Compensation Commission.

\section{Introduction}

\subsection{Historical Evolution of the Darfur Conflict}

Darfur is located in the western region of the Republic of Sudan and is approximately the size of France (Robert, 2006. p.3). It is divided into five ethnic zones which are North Darfur, South Darfur, West Darfur, Eastern Darfur and Central Darfur. It has an estimated population of about 5.6 million people who are predominantly Muslims (Darfur Population as of 2013 Census). The most populated area is inhabited by non-Arabs in the Western Darfur states (Robert, 2006). Southern Darfur is inhabited by cattle and camel nomads. They are practically of Arab origin and speak Arabic. Northern Darfur is the home of camel nomads, a small minority of whom are Medial Arabs.

Before the fall of the Darfur Sultanate in 1874, three dynasties ruled Darfur and these are the Daju, Tunjur and Keira (Fahey and Spaulding, 1974. p.108). Although superiority and domination in Darfur favoured the Tunjur, ethnic and political evolutions later altered the course of history. This was evident by the suppression of the Tunjur by the Keira. The role in change-over led to what was described as 'an Arab of exalted lineage' whose coming to Darfur resulted directly in the later version of the traditions and indirectly to the establishment of the Keira dynasty (Fahey and Spaulding).

The domination of the Keira dynasty in Darfur saw the light of the $21^{\text {st }}$ century as the Arabs later separated themselves from the Fur whom they considered to be black Africans (Gamal, 2008. p.160). The objective of the Arabs was to transform the African Sahel, which lies between the Red Sea and the Atlantic Ocean, into a pure Arab region. This task seems most difficult to achieve as 70 percent of the total population in Darfur is black-Africans (Gamal, 2008). The continuous competition for domination therefore sparked up a conflict that began in 2003.

The conflict in Darfur has boosted ethnic tensions between farmers and herdsmen, Africans and Arabs, competing for pasture, agricultural land and water. Some of the victims of these conflicts are non-Arabs or the African tribal groups of Darfur, primarily the Fur, the Masaliet and the Zaghawa, but also, the Tunjur, the Birgrid and the Dajo (Reeves, 2005). These inhabitants have long been politically and economically marginalized. In recent years, the government of the National Congress Party (NCP) dominated by members of the National Islamic Front (NIF) based in Khartoum refused to control increasing violent Arab Militia raids on African villages in Darfur. Increasing Competition between Arab and African tribal groups for scares resources, especially agricultural and grazing land has led to advancing desertification in the Sahel region (Reeves, 2005). Although, the conflict seems to be tribal in nature, it is interconnected with governmental policies and political issues.

The African Union High-Level Panel on Darfur (AUPD) reports that the root causes of the Darfur conflict can be traced from a history of neglect of the Sudanese peripheries from the pre-colonial to the post-colonial era of the modern 
Sudanese state (Report of the African Union High Level Panel, 2009. para.281). The conflict is a manifestation of Sudan's inequitable distribution of wealth and power, which the Panel describes as "Sudan's crisis in Darfur" (Report of the African Union High Level Panel). Recently, the Sudanese government banned at least four foreign humanitarian agencies from working in the eastern region of the country (Annette, 2012). In addition to the recent developments in the East, humanitarian access remains severely hampered in Darfur and has been completely blocked in South Kordofan and Blue Nile (Annette, 2012).

The conflict in Darfur started in February 2003, when the Sudan Liberation Army (SLA) attacked and captured the town of Gulu. Another attack was launched in March to recapture Gulu in a fierce fight that killed one hundred and ninety five government soldiers (Robert, 2006). At least 400,000 people have been reportedly killed and more than 2.5 million civilians displaced (Omer, 2008. p.9). Those displaced now live in displaced persons camps in Sudan or in refugee camps in neighbouring Chad. More than 3.5 million people - men, women and children - are completely reliant on international aid for survival.

\section{Darfur Conflict and International Law}

The Darfur conflict challenges international law and the responsibility to protect. In the outcome document of the HighLevel Plenary Meeting of the General Assembly in September 2005, the responsibility of individual states to protect its citizens against genocide, ethnic cleansing, war crimes and crimes against humanity was invoked (Heads of States Agreement on the Responsibility to Protect, 2005. para.138). The Darfur conflict reveals that these issues have not been addressed and the recorded number of deaths has been massive. The conflict has been described as genocide (Robert, 2006).

The emergence of human rights and international humanitarian law principles under international law has changed the traditional view on state responsibility which focused on wrongful conduct of the state and not individuals. In view of the new dispensation, 'responsibility to protect' is not geared only to the state but also to individuals involved in breaching the law, and if their guilt is established beyond reasonable doubt, they have the duty to pay reparations adequately (Shelton, 2000. p.1). However, the provision of the Rome Statute provides that the Court shall be the primary vehicle for the enforcement of human rights and international humanitarian law with respect to reparations (Rome Statute of the International Criminal Court, 1998. Art.75(1)). Reparation therefore is the basis upon which remedies can be made available to victims of armed conflicts with the view of placing them in such a situation they would have been in the absence of any violation of their rights.

\section{The Need for Reparation}

After armed conflicts or repression, societies are often confronted by legacies of systematic or widespread human rights violations whose perpetrators remain unaccountable and victims un-redressed (The Rabat Report, 2009. p.9). In post conflict societies, political leaders and civil society organizations have used transitional justice mechanisms to pursue justice, establish peace, and promote reconciliation. These mechanisms have included criminal prosecution, truth commissions, and reparations programs (The Rabat Report, 2009). In some cases, communities established measures of remembrance, such as memorials, and attempts at reconciliation. Among these transitional justice mechanisms, reparation programs are arguably the most focused on the rights and welfare of victims and survivors (The Rabat Report, 2009).

Shelton confirms that reparation, public apologies and other mechanisms of transitional justice are the new mantras of the post-cold war era (Shelton, 2000. p.137). Their fundamental purpose is to foster reconciliation in societies that have experienced massive human rights violation and to promote reform, the ultimate aim being the removal of tension (Shelton, 2000). The primary function of justice is rectification of the wrong perpetrated against the victims. Compensation can only provide something equivalent in value to that which is lost whereas restitution restores that which is taken (Shelton, 2000). Monetary compensation is thus quite central to this process because, "Money is the common measure of valuable things" (Shelton, 2000). Thus, the most cardinal goal of the process of reparation is the "rehumanisation" of the victims and restoration of their psychological and social functions, including re-integration and rehabilitation.

\section{International and Regional Legal Framework Pertaining Reparation}

The right to some form of remedy for the violation of human rights has been recognised by most legal systems in the 
world as extremely important, especially for victims (Preliminary Statement: The UN Declaration on the Right of Indigenous People, 2012). The UN Declaration on the Rights of Indigenous People (UNDRIP), for example recognizes that: "indigenous people are equal to all other people," "indigenous people, in the exercise of their rights, should be free from discrimination of any kind". By virtue of their existence as human beings, they are entitled to all human benefits. Any breach of their rights will demand reparation as a remedy. In the Chorzow Factory (Germany v. Poland) case the Permanent Court of International Justice held that (Case Concerning Chorzow Factory, 1927. para.55):

It is a principle of international law that the breach of an engagement involves an obligation to make reparation in an adequate form. Reparation therefore is the indispensable complement of a failure to apply a convention and there is no necessity for this to be stated in the convention itself.

It is therefore an international law principle that the international human rights and humanitarian law systems are the bed-rocks upon which remedies are made available to victims of armed conflicts in the form of reparation (Preliminary Statement, 2012). For the purposes of clarification, it is important to digest the basis for remedies under these two legal systems.

\subsection{International Human Rights Law}

Remedies for human rights violations are provided for in a number of international human rights instruments. The UDHR provides that "Everyone has the right to an effective remedy by the competent national tribunals for acts violating the fundamental rights granted him(sic) by the constitution or by law" (The Universal Declaration on Human Right, 1948. Art.8). This provision is pari materiae with Article 2(3) of the International Covenant on Civil and Political Rights (ICCPR) which also provided for remedying human rights violations. The process of reparation is also regarded as an important form of remedy and has been given due consideration by some legal documents as a way of compensation to victims of arm conflict. The International Covenant on the Elimination of All Forms of Racial Discrimination (ICERD) provides that (International Convention on the Elimination of all forms of Racial Discrimination, 1969. Art.6):

States Parties shall assure to everyone within their jurisdiction effective protection and remedies through the competent national tribunals and other State institutions against any acts of racial discrimination which violate his (sic) human rights and fundamental freedoms contrary to this Convention, as well as the right to seek from such tribunals just and adequate reparation or satisfaction for any damage suffered as a result of such discrimination.

The Basic Principles and Guidelines on the Right to a Remedy make a distinction between 5 forms of reparations which include: restitution, compensation, rehabilitation, satisfaction and guarantees of non-repetition (Basic Principles and guidelines on Reparation, 2005. Art.18). The provisions of the Convention against Torture and other Cruel, Inhuman and Degrading Treatment or Punishment (CAT) are to the effect that each state party shall ensure in its legal system that the victims of an act of torture obtain redress and an enforceable right to fair and adequate compensation, including the means for as full rehabilitation as possible. In the event of death of the victim as a result of an act of torture, his/her dependants shall be entitled to compensation (Convention against Torture, 1987. Art.14).

\subsubsection{Regional Instrument for the Right of Reparation}

Article 25 of American Convention on Human Rights (ACHR) establishes the basic principles of redress for victims of violation of human rights while Articles 63(1) and 68 give the most extensive provisions for redressing victims of human rights abuses by prescribing various forms of remedies (American Convention on Human Right, 1969). In the benchmark case of Velasquez v. Honduras, the Inter-American Court of Human Rights stressed that the enforcement of reparation to victims of human rights violations should not be subject to modification, suspension or limitation at the domestic level (Judgement of 26 June 1989, Inter-American Court of Human Right. p.290). The Court further clarified the general principles regarding reparation as follows:

It is a principle of international law, which jurisprudence has considered even a general concept of law, that every violation of an international obligation which results in harm created a duty to make adequate reparation.

The African Charter on Human and Peoples' Rights provides for a peoples' right to compensation in the event of dispossession of their wealth and resources. "In case of spoliation, the dispossessed people shall have the right to the lawful recovery of their property as well as to an adequate compensation" (African Charter of Human and Peoples Right, 1981. Art 21(2)). The European system also provides reparation for victims' of human right violations. Article 5(5) of the European Convention on Human Rights and fundamental freedom (ECHR) provides that "Everyone who has been the victim of arrest or detention in contravention of the provisions of this article shall have an enforceable right to compensation" (Convention for the Protection of Human Rights and Fundamental Freedom, 1950). The situation obtained 
in Darfur has challenged these provisions and therefore, the victims deserve compensation in the form of reparation.

\subsection{International Humanitarian Law}

In the context of international humanitarian law, the need to recognize the right of the victim is informed by the belief that human persons have inviolable rights even during armed conflict (Zegveld, 2003. p.502). The rationale of international humanitarian law is to go beyond the interstate levels of states and [to reach] for the level of the real beneficiaries of humanitarian protection, i.e. individuals and group of individuals (Abi-Saab, 2000. p.234). The victim's right to a remedy in the first place is dependent on his or her right under international law being violated (Zegveld, 2003. p.503). It is a secondary right which is derived from a primary substantive right that has been infringed (Zegveld, 2003). Nevertheless, there is a world of difference between recognising the existence of such a right and enforcing such a right through a claim. States have so far been unwilling to entitle explicitly and in general, victims of violations of international humanitarian law claiming reparation (Zegveld, 2003). In the case of Gouriet v. Union of Post Office Workers the House of Lords acknowledged that, "a right without a remedy is no right at all" (Gouriet v. Union of Post Office Workers, 1978). Thus, there is a need to afford this remedy to victims of international crimes particularly to the victims of the Darfur conflict. Such remedies will at least give them a sense of fairness, qualifying them as members of the human family.

The interests of victims of human rights violations have been recognized by the General Assembly resolution 60/147 (Basic Principles and Guidelines on Reparation, 2005). This resolution established the basic principles and guidelines on the right to a remedy and reparation for victims of gross violations of international human rights law and serious violations of international humanitarian law. Principle 8 and 10 provides that states must afford appropriate remedies to victims of violations of international humanitarian law, including access to justice (Basic Principles and Guidelines on Reparation, 2005). According to principle 11, the content of this right include access to justice, reparation for human suffering and access to factual information concerning violations (Basic Principles and Guidelines on Reparation, 2005). These UN Principles have been backed up by other initiatives. For example, the Hague Agenda for Peace and Justice for the $21^{\text {st }}$ century defined the implementation of international law as a dominating theme and recommended that (UN Doc A/54/98):

The Hague Appeal will advocate changes in the development and implementation of the laws in both fields (international humanitarian law and human rights law), in order to close critical gaps in protection and to harmonise these vital areas in international law.

Articles 7 and 8 common to the four Geneva conventions of 1949 clearly affirms the rights granted to protected persons. An investigation into these conventions demonstrated that a number of rules refer explicitly to concept such as "right", "entitlement" or "benefit". Additional Protocol II to the Geneva Conventions presupposes the existence of such rights. (Protocol Additional to the Geneva Convention of 1949, 1978. Art.6(2))

Case law also provides for an inference that the Law of The Hague also bestows individuals with rights to reparation. In the case of Dedovic v. Kok et al, the Amsterdam District Court (Netherlands) implicitly recognised the idea of individual rights in the field of international humanitarian law (Judgement of the Amsterdam District Court, 2000. para.5.5.22 ). However, there are hurdles for the realisation of remedies for victims of war crimes provided by international criminal tribunals (Zegveld, 2003). The key emphasis on these tribunals has been on panel sanctions, and focus on victims and their remedies have been restricted. Nevertheless, some degree of attention has been given to victims and their remedies. In Resolution 827 of 1993 that adopted the Statute of the International Criminal Tribunal for the Formal Yugoslavia (ICTY), the UN Security Council decided that (United Nations Security Council Resolution 827, 1993):

The work of the Tribunal shall be carried out without prejudice to the right of victims to seek, through appropriate means, compensation for damages incurred as a result of violations of international humanitarian law.

Both the International Criminal Tribunal for Rwanda (ICTR) and ICTY statutes, and the Rules of Procedure and Evidence of the Special Court for Sierra Leone provide for the restitution of property or the proceeds thereof to victims and in this context, a trial chamber may determine the rightful owner of the property at issue United Nations Security Council Resolution 827). The Rules of Procedure and Evidence of the Special Court for Sierra Leone embody a similar provision. Rule 105 on compensation to victims states that:

The Registrar shall transmit to the competent authorities of the states concerned the judgment finding the accused guilty of a crime which has caused injury to a victim.

Pursuant to the relevant national legislation, a victim or person claiming through him may bring an action in a national court or other competent body to obtain compensation.

For the purposes of a claim made under sub-rule (b), the judgment of Special Court shall be final and binding as to the criminal responsibility of the convicted person for such injury. 
From this analysis, it can be concluded that the victims of human right violations depend on the availability of national remedies. In the absence of a national court with the power and the will to award reparations, victims are left without a legal recourse. Thus, the UN Principles on the Right to a Remedy aim to fill this existing domestic gap. Principles 4 and 5 deals with violations of international humanitarian law that constitute crimes under international law. The establishment of the ICC was aimed at achieving similar goals (Zegveld, 2003). Thus, concerned by lack of attention given to victims by ICTY and ICTR statutes, the Statute of the International Criminal Court (ICC) contains more possibilities of redress. Article 75(1)(2) of the Statute of the ICC stipulates that (Rome Statute of the International Criminal Court, Art.75(1)(2)):

1. The Court shall establish principles relating to reparations to, or in respect of, victims, including restitution, compensation and rehabilitation. On this basis, in its decision the Court may, either upon request or on its own motion in exceptional circumstances, determine the scope and extent of any damage, loss and injury to, or in respect of, victims and will state the principles on which it is acting.

2. The Court may make an order directly against a convicted person specifying appropriate reparations to, or in respect of, victims, including restitution, compensation and rehabilitation.

The ICC Statute goes further to explain that a Trust Fund shall be established by a decision of the Assembly of States Parties for the benefit of victims of crimes within the jurisdiction of the Court, and of the families of such victims (Rome Statute of the International Criminal Court, Art.79(1)). It also remarks that nothing contained in it shall be interpreted as prejudicing the rights of victims under national or international law. Thus, the Rome Statute goes beyond the treatment of victims under the ICTY and ICTR statutes, as it gives the victim locus standi on his or her own. This argument therefore seeks to justify reparation as a remedy under international law.

\section{Reparations for Darfur and the Need for a Compensation Commission}

The International Commission of Inquiry on Darfur proposed to the UN Security Council to establish a Compensation Commission which would complement the ICC (Reeves, 2005. para.590). States are therefore obliged not only to act against the perpetrators but also to cater for the interests of victims. The main focus of the Commission would be to redress the rights of victims of heinous crimes committed in Darfur, and also hold accountable those accused of violations.

The necessity for reparations to victims of crimes perpetrated in Darfur is reaffirmed by the gravity of damage engendered by the armed conflict (Reeves, 2005. para.591). It must therefore be necessary to determine whether or not the perpetrators of these international crimes have been identified. The need to afford reparation to the victims is predicated on pragmatic and moral grounds, as well as on legal grounds (Reeves, 2005. para.592). It recognises that although the perpetrators may continue to enjoy impunity, the global community may not ignore the plight of the victims. It should at least lessen their suffering by ensuring that the Sudanese Government makes reparation to the victims. This agenda can be realised by enforcing all national authorities charged with the responsibility of protecting the Sudanese citizens. Therefore, centre to the reparation program is the enforcement of the national system, particularly the judiciary as it remains the only machinery though which justice can be made available to the victims of the Darfur conflict.

\subsection{The Effectiveness of the Reparation Regime}

Khartoum's stubborn refusal to compromise by handing over to the ICC the alleged perpetrators of international crimes in Darfur means that many victims will not have the benefit of seeing their attackers held accountable by a court of law. To seek remedies from the international criminal jurisdiction seems to be very slow or bureaucratic. Professor Williamson argues that the international criminal jurisdictions are "giants without legs and arms" (Williamson, 2006. p.26). It may be right to compliment that, without cooperation of the state concerned; the only source of support for the giant is the international community.

In respect of the situation in Darfur, there are four active cases (Report of the International Criminal Court to the United Nations Secretary General, 2010/11. p.3). In The Prosecutor v. Abdallah et al, on 7 March 2011 Pre-Trial Chamber I confirmed charges of war crimes in connection with an attack on an African Union mission, sending the case to trial (Report of the International Criminal Court for 2010/2011). Arrest warrants remain outstanding in The Prosecutor v. Ahmad Muhammad et al; Prosecutor v. Omar Hassan Ahmad Al Bashi;r as well as The Prosecutor v. Abdel Raheem Muhammed Hussien.

In accordance with Security Council resolution 1593 (2005), the Prosecutor presented his twelfth and thirteenth reports to the Council on 9 December 2010 and 8 June 2011, on the status of the investigation into the situation in Darfur. 
He highlighted lack of cooperation by the Sudanese Government, the continuation of the alleged crimes and the need to execute the outstanding arrest warrants, the end goal being to stop human rights violations in Darfur (Report of the International Criminal Court for 2010/2011). It is important therefore to provide national remedies like the establishment of a compensation commission. The setting up of truth commission and the stigmatisation of the perpetrators are regarded as making amends to the victims of atrocities (Hazan, 2006. p.44).

With respect to Darfur, reparations will be the price of the country's return to peace and stability. Alongside political issues, there are also societal dimensions which concern the Darfur victims. There are some victims who may feel that reparation money cannot make good what is irreparable and cannot be acceptable because it is blood money for the departed (Hazan, 2006). Others may consider, on the contrary, that the suffering caused by the conflict must result in some form of reparation, even if it can never bring back the years that have been lost. An illustrative example of this is the case of South African victims of apartheid. The Truth Commission was based on a transaction: the perpetrators were granted amnesty, and the victims of apartheid atrocities received reparations in exchange (Hazan, 2006). However, besides individual attitudes of the victims, the entire society should also be taken into account (Alfonsin, 2002. p.173).

A 1998 survey reveals that most South Africans felt that the Truth Commission had failed to achieve reconciliation between black and white communities (Storey, 1997. p.3). Most believed that justice was a prerequisite for reconciliation rather than an alternative to it. There was also a perception that the Truth Commission was weighted in favour of the perpetrators of human rights abuses and therefore, there was unhappiness of amnesty being granted for human rights abuses committed by the apartheid government (Storey, 1997). On the part of the apartheid government, former president F.W. de Klerk appeared before the Commission and reiterated his apology for the suffering caused by apartheid. He pleaded for forgiveness and reconciliation which he viewed as desirable for the achievement of a democratic South Africa (Storey, 1997). In a special report, the BBC described such criticisms as stemming from a "basic misunderstanding" about the Truth Commission's mandate which was to uncover the truth about past abuses, using amnesty as a mechanism, rather than to punish past crimes.

With regards to the Darfur conflict, the fundamental issue is the nature of this ethico-political transaction: how acceptable are its terms? This question thus concerns not only the victims but all societies in the Darfur region. The government of Indonesia established a compensation project to the victims of human rights violation in Indonesia on condition that they forgave the alleged aggressors (Alfonsin, 2002). The transaction which placed the victims in a morally shocking position activated a feeling that they were selling their conscience and therefore it was later abandoned.

In the final analysis, it can be noted that the acceptability of the terms of the ethico-financial transaction in Darfur will depend on the choices made by the society including the victims. Reparation payment will either bring tension into the process of societal normalisation or will contribute to it depending on how they are interpreted.

To find an equitable solution to the Darfur situation, the AUPD suggest that the complex question of accountability, arising from the conflict, should not be left to Darfurians alone to grapple with. These issues should engage all Sudanese, who are legitimate stakeholders in the justice and reconciliation discussion on Darfur, since the matter has national, legal and political significance (Zegveld, 2003. p.49). In the light of this, it must be noted that justice, accountability, reconciliation and healing are inter-link and inter-dependent and must be looked at broadly. Consequently, the solution in this area must necessarily be holistic, and given the range of measures that will be required, they should also be procedurally integrated into a workable system (Zegveld, 2003).

In addition, and of great significance to the process of negotiation, a number of measures have been suggested by the AUPD (Zegveld, 2003. p.88-89). One among them is a comprehensive, independent and integrated national criminal justice process, which shall include investigations and re-invigoration of all aspects of the Special Criminal court on the Events in Darfur (SSCED) as the principal forum for delivering criminal justice for crimes relating to the conflict in Darfur. The other suggestion is a Hybrid Criminal Court, which will exercise original and appellate jurisdiction over individuals, who appear to bear particular responsibilities for the gravest crimes committed during the conflict in Darfur and to be consulted by judges of Sudanese and other nationalities.

\section{Conclusion}

The Darfur conflict presents a picture of the worst form of human rights violation of the $21^{\text {st }}$ century. While the ICC is still in search for substantial evidence to deliver its final judgment, the UN General Assembly has provided a realm of ratified treaties and conventions as the basis for compensating the victims of such atrocities by virtue of reparation. Most of the treaties and conventions have been discussed above with the view of initiating a platform in support of the reparation regime through which the plight of the victims can be redressed. It is worth noting that, a similar procedure has been tested before and the results were particularly successful in resolving the dilemma of the post-apartheid South Africa 
through a compensation commission. In this regard, the international community should act fast in adopting the same approach with much emphasis on the concept of reparation to deal with the Darfur crisis. It is the only means through which justice can be made available in a timely and peaceful manner to the victims of human rights violations in Darfur.

There is also a pressing need to strengthen the capacity of the national judicial authorities in The Sudan. These authorities includes but not limited to national courts, police officers national human rights and other non-governmental organizations, governmental structures particularly the legislative arm which is charged with the responsibility of making laws and other subjects like lawyers and social workers. Their role will constitute a notochord in facilitating the reparation program and justice will be guaranteed to both the state and all those who have been affected by the conflict in one way or the other.

\section{References}

Abi-Saab G. (2000). "The Specificities of Humanitarian Law". 94 American Journal of International Law, 2 at 243

Alfonsin R. (2002). Argentina's first elected president after the collapse of the military regime cited in Olson L. "mechanisms complimenting prosecution. 84 International Review of the Red Cross, 845 at 173

Annette L. (2012). Khartoum's Pattern of Neglect Continues in Eastern Sudan as Government Expels Aid Grou. Available at http://enoughproject.org/blogs/Khartoum-pattern-neglect-continues-eastern-sudan-government-expels-aid-groups [Accessed 11 February 2014]

Darfur Population as of 2013 Census. Available at http://exploredia.com/darfur-population-2013. [Accessed 11 February 2014]

Fahey R. And Spaulding J. (1974). Kingdoms of the Sudan: Studies in African History. Harper and Row Publishers Inc, USA.

Gamal A. (2008). Why has Darfur's Indigenous Population Been Put at Risk?, Peace Review: A Journal of Social Justice. Routledge Publishers London, UK

Hazan P. (2006). "Measuring the impact of punishment and forgiveness: A frame work for evaluating transitional justice", 88 International Review of the Red Cross, 861 at 44

Omer Y. (2008). The Darfur Situation and the International Criminal Court: An Appraisal. Journal of Politics and Law. Vol.1, No.3

Reeves E. (2005). Genocide in Darfur-How the Horror Began. Available at http://www.sudantribune.com/spip.php?article11445. [Accessed 11 February 2014]

Reeves E. (2005). Report of the International Commission of Inquiry on Darfur to the United Nations Secretary-General. IDEA publishers New York

Report of the African Union High-Level Panel on Darfur. Peace and Security Council 207th meeting of the Heads of States and Government, 29 October 2009, Abuja, Nigeria. AU Doc. PSC/AHG/2(ccvii).

Report of the International Criminal Court to the United Nations for 2010/11. Summary of Sixty-Sixth Session, Item 75 of the provisional agenda. UN Doc. A/66/309 of 19 August 2011.

Robert O. (2006). Genocide in Darfur: Investigating the atrocities in Sudan. Routledge Taylor and Francis Group New York.

Shelton D. (2000). Remedies in International Law. Oxford University Press, Oxford.

Storey P. (1997). A different kind of Justice: Truth and Reconciliation in South Africa. The Christian Century Chicago, United States of America.

The Rabat Report: The Concept and Challenges of Collective Reparation. International Center for Transitional Justice, 2009

Williamson C. (2006). Justice empowered or Justice hampered: The International Criminal Court in Darfur. African Security Review Journal. Routledge Taylor and Francis group (Pretoria) South Africa.

Zegveld L. (2003). "Remedies for Victims of Violations of International Human Rights Law", 85 International Review of the Red Cross, 851 at 497.

Legal Instruments

African Charter on Human and Peoples' Rights, adopted on 27 June 1981, entered into force 21 October 1986. OAU Doc. CAB/LEG/67/3 rev. 5, 21 I. L. M. 58(1982).

American Convention on Human Rights (Pact of San Jose). Adopted on 22 November 1969 and came into force on 18 July 1978.

Basic Principles and Guidelines on the Right to a Remedy and Reparation for Victims of Gross Violations of International Human Rights Law and Serious Violations of International Humanitarian Law. Adopted by General Assembly Resolution 60/147 of 16 December 2005.

Case concerning Chorzow Factory (Germany v Poland) PCIJ, Ser. A No.9, 1927, para 55 at 21.

Convention against Torture and other Cruel, Inhuman or Degrading Treatment or Punishment, G.A. res. 39/46, [ annex, 39 U.N. GAOR Supp. (No. 51) at 197, U.N. Doc. A/39/51(1984) ], entered in to force June 26, 1987.

Convention for the Protection of Human Rights and Fundamental Freedom. CETS No.005. Adopted and open for Signature on 4 November 1950 and came into force on 3 September 1953.

Gouriet v. Union of Post Office Workers. House of Lords Judgement on Appeal, [1978] AC 435.

Head of states and governments agree to the following text on the Responsibility to Protect in the outcome document of the High-Level Plenary Meeting of the General Assembly in September 2005,Para 138. Available at http://www.responsibilitytoprotect.org /index.php/component/content/article35>.

International Convention on the Elimination of All Forms of Racial Discrimination. Adopted by the General Assembly resolution 2106 (XX) of 21 December 1965 and entered into force on 4 January 1969.

Judgement of 26 June 1989, Inter American Court of Human Rights. OAS/Ser.L/V/III.17,Doc.13.

Judgement of the Amsterdam District Court, 6 July 2000.

Preliminary Statement: The UN Declaration on the Right of Indigenous People and International Reparation. April 2012. Available at http://internationalreparation.worldpress.com/. [Accessed 15 November 2013].

Protocol Additional to the Geneva Convention of 12 August 1949, and relating to the Protection of victims of International Armed Conflicts (Protocol II), $7 / 12 / 1978$.

Rome statute of the International Criminal Court. A/CONF.183/9 of 17 July 1998.

The Rabat Report: The Concept and Challenges of Collective Reparation. International Centre for Transitional Justice, New York.

The Universal Declaration on Human Rights adopted by the UN Human Rights Commission on 10/12/1948 and entered into force on 18/07/1978. The Universal Declaration on Human Rights adopted by the UN Human Rights Commission on 10/12/1948 and entered into force on 18/07/1978.

UN Doc. A/54/98.

United Nation Security Council Resolution 827 of 25 May 1993 adopting the Statute of the International Criminal Tribunal for the Former Yugoslavia. Doc. S/RES/827, 1993. 